\title{
No relationship between the distribution of mast cells and the survival of stage IIIB colon cancer patients
}

\author{
Qing Xia ${ }^{1,2}$, Xiao-Jun $\mathrm{Wu}^{1,3}$, Qiang Zhou ${ }^{1,2,5}$, Jing-Zeng ${ }^{1,4}$, Jing-Hui Hou ${ }^{1,4}$, Zhi-Zhong Pan ${ }^{1,3}$ and \\ Xiao-Shi Zhang ${ }^{1,2^{*}}$
}

\begin{abstract}
Background: Mast cells promote the progression of experimental tumors and might be a valuable therapeutic target. However, the relevant clinical evidence is still controversial. This study analyzed the relationship between the distribution of mast cells and the survival of patients with colon cancer to study whether mast cells contribute to tumor progression.

Materials and methods: Ninety-three cases of pathologically confirmed primary cancer tissues matched with adjacent normal mucosa, metastases of regional-draining lymph nodes and regional-draining lymph nodes without metastases were collected from stage IIIB colon carcinoma patients between January 1997 and July 2004 at the Cancer Center of Sun Yat-Sen University. Tryptase-positive mast cells were counted. The relationships of the distribution of mast cells with clinicopathologic parameters and 5-year survival were analyzed.

Results: Although the mast cell count in the mucosa adjacent to the primary colon cancer was significantly higher than that in the stroma of the primary colon cancer, no difference in mast cell counts was observed between the stroma in lymph node metastasis and the lymph tissue adjacent to the metastasis. Additionally, the mast cell count in the regional-draining lymph node without the invasion of cancer cells was significantly higher than that in the stroma of lymph node metastasis and adjacent lymph tissue. However, none of those mast cell counts was related to 5-year survival.
\end{abstract}

Conclusion: Although mast cell count varied with location, none of the mast cell counts was related to 5-year survival, suggesting that mast cells do not contribute to the progression of stage IIIB colon cancer.

Keywords: Mast cells, Colon cancer, Survival, Progression

\section{Background}

In addition to the genetic alterations of cancer cells, it is believed that the infiltration of immune cells, such as dendritic cells, $T$ cells, macrophages, and mast cells, are involved in the progression of colon cancer [1-6]. For example, mast cells might impact tumor progression by induction of angiogenesis, tissue remodeling, immune cell recruitment and direct cytotoxicity against cancer cells [7-9]. Because c-kit inhibitors such as imatinib and sunitinib have been approved in

\footnotetext{
* Correspondence: zxs617@hotmail.com

'State Key Laboratory of Oncology in South China, Sun Yat-sen University Cancer Center, Guangzhou 510060, China

Full list of author information is available at the end of the article
}

clinical practice and mast cells depend on c-kit, mast cells might be a new target for cancer therapy [10]. In animal models, polyps are infiltrated by pro-inflammatory mast cells and their precursors. Depletion of mast cells, either pharmacologically or through the generation of chimeric mice with genetic lesions in mast cell development, leads to a profound remission of existing polyps [11]. The interaction between mast cells and Treg cells shifts the local balance of immune surveillance in favor of tumor progression [12]. However, the relevant clinical evidence is controversial. For example, although Yodavudh and Nielsen reported that mast cell count was an independent prognostic factor for 
patients with colorectal cancer, this result was not confirmed by other groups [13-18].

Because these previous studies focused on the infiltration of mast cells into primary colorectal cancers and the function of mast cells might vary with their location in cancer tissue, it is reasonable to examine the distribution of mast cells and its relationship with the progression of colon cancer to identify the role of mast cells in this process. Therefore, the current study examined the mast cell counts in primary and metastatic tumors, as well as regional-draining lymph nodes without metastases, to study whether mast cells contribute to the progression of colon cancer.

\section{Materials and methods Materials}

Ninety-three cases of pathologically confirmed primary tumor tissues matched with adjacent normal colon mucosa, metastases of regional-draining lymph nodes and regional-draining lymph nodes without metastases were collected from stage IIIB colon cancer patients between January 1997 and July 2004 at the Cancer Center of Sun Yat-Sen University. All the patients underwent radical surgery, and none of them had undergone either chemotherapy or radiotherapy before the collection of the samples. The histopathologic characteristics of the colon carcinoma tissue specimens were confirmed by blinded review of the original pathology slides. The TNM classification system of the American Joint Committee on Cancer (edition 7) was used for clinical staging, and the World Health Organization classification (2000 version) was used for pathologic grading. The study was conducted in accordance with the Helsinki Declaration and approved by the Ethics Committee of our institution. Patients were informed of the investigational nature of the study and provided their written informed consent.

\section{Follow-up of patients}

Follow-up was provided to all of the patients. All patients were observed at 3-month intervals during the first year, once every 6 months in the second year, and by telephone or mail communication once every year thereafter for a total of 5 years. If recurrence or metastasis occurred, 5-Fu-based chemotherapy was administered according to the NCCN guidelines. Overall survival (OS) was defined as the time from surgery to death or was censored at the last known living date.

\section{Immunohistochemistry}

The specimens were fixed in formaldehyde and embedded in paraffin. Tissue sections of $5 \mu \mathrm{m}$ thickness were cut, dried, deparaffinized, and rehydrated in a series of alcohols and xylene before antigen retrieval by pressure cooker treatment in citrate buffer $(\mathrm{pH}$ 6.0) for 3 minutes. Then endogenous peroxidase was blocked with $3 \%$ hydrogen peroxide incubation. Mouse antihuman mast cell tryptase monoclonal antibody (at 1:160 000 dilution, Serotec, Oxford, UK) was used. Immunostaining was performed using an EnVision+ Dual Link Kit (DakoCytomation, Denmark) according to the manufacturer's instructions. The samples were developed with a substrate-chromogen solution [3,3'-diaminobenzidine dihydrochloride (DAB)] for 3-5 minutes. Sections were then counterstained with hematoxylin and mounted in non-aqueous mounting medium.

\section{Mast cell evaluation}

The count of tryptase-positive mast cells in the cancer stroma of a primary tumor is denoted as $\mathrm{MCC}_{\text {stroma }}$. The stained sections were first screened under lower power $(\times 100)$ to identify the areas with the most mast cells in the tumor stroma. $\mathrm{MCC}_{\text {stroma }}$ was then counted under $\times 400$ magnification $\left(1 \mathrm{~mm}^{2}\right.$ per $\left.\mathrm{HP}\right)$ in five fields of vision with an ocular micrometer. The number of mast cells in every field is expressed as MC/HP. Mean $\mathrm{MCC}_{\text {stroma }}=$ total number of mast cells in the five fields divided by five. Additionally, the mast cell counts in the normal mucosa adjacent to the colon cancer $\left(\mathrm{MCC}_{\mathrm{adja}}\right.$ cent), in the stroma of matched lymph node metastasis $\left(\mathrm{MCC}_{\mathrm{slnm}}\right)$, in the normal lymph tissue adjacent to the lymph node metastasis $\left(\mathrm{MCC}_{\mathrm{alnm}}\right)$ and in the regionaldraining lymph node without metastasis $\left(\mathrm{MCC}_{\text {lnwm }}\right)$ were evaluated as $\mathrm{MCC}_{\text {stroma }}$. All evaluated section were obtained from areas far from the area of necrosis and $\mathrm{H}$. E. staining was reviewed in uncertain cases. The mast cell count in each section was scored independently by two pathologists with no prior knowledge of clinicopathologic parameters. The inter-observer agreement for the MCC was $81 \%$. Disagreements were re-evaluated until a consensus was reached.

\section{Statistical analysis}

Statistical analyses were performed using SPSS 13.0 software for Windows (SPSS Inc, Chicago, IL, USA). Descriptive statistical tests, including the mean, standard deviation, and median, were calculated according to standard methods. The relationships between the various clinicopathologic characteristics and the MCC parameters were compared and analyzed using chisquare tests, likelihood ratio, and linear-by-linear association, as appropriate. The non-parametric Wilcoxon signed ranks test and Kruskal-Wallis test were used to evaluate the significance of the differences of the mean ranks. Univariate and multivariate analyses were based on the Cox proportional hazards regression model. A two-tailed $\mathrm{P}<0.05$ was considered statistically significant. 


\section{Results}

The distribution of mast cells

The cytoplasm of mast cells stained brown. In primary tumor tissue, the mast cell count in normal mucosa adjacent to colon cancer $\left(\mathrm{MCC}_{\text {adjacent }}\right)$ was significantly higher than that in the stroma of the primary colon cancer $\left(\mathrm{MCC}_{\text {stroma }}\right)(\mathrm{P}=0.000)$. However, no difference in mast cell count was observed between the stroma in lymph node metastasis $\left(\mathrm{MCC}_{\mathrm{s} \operatorname{lnm}}\right)$ and the adjacent lymph tissue $\left(\mathrm{MCC}_{\mathrm{alnm}}\right)(\mathrm{P}=0.752)$. Additionally, the mast cell count in the regional-draining lymph node without metastasis $\left(\mathrm{MCC}_{\mathrm{lnwm}}\right)$ was significantly higher than that in the lymph tissue adjacent to lymph node metastasis $\left(\mathrm{MCC}_{\mathrm{alnm}}\right)(\mathrm{P}=0.000)$ (Figure 1 andTable 1$)$.

\section{Relationships between the distribution of mast cells and clinicopathologic characteristics}

We used the chi-square test to assess the relationships between the distribution of mast cells and clinicopathologic characteristics. The results show that $\mathrm{MCC}_{\mathrm{alnm}}$ (the mast cell count in the normal lymph tissue adjacent to metastasis) was correlated with pathologic classifications and pathologic grades. $\mathrm{MCC}_{\mathrm{alnm}}$ was higher in papillary and tubular adenomas than that in mucoid and signet ring adenomas. Additionally, higher $\mathrm{MCC}_{\mathrm{alnm}}$ also occurred in lower-grade colon cancers, while higher $\mathrm{MCC}_{\text {lnwm }}$ occurred in male patients (Table 2).

\section{Survival analysis with univariate analysis}

By the end of the 5-year follow-up, 66 patients with stage IIIB colon carcinoma were alive, so the 5 -year survival rate was $70.9 \%$. Based on univariate analysis, although the pathologic classification was a predictor of $\mathrm{OS}(\mathrm{P}=0.033)$, age, gender, location of primary tumor, pathologic grade, growth pattern, and tumor invasive depth showed no prognostic significance. More importantly, the mast cell counts in the primary tumor, metastasis and regional-draining lymph node
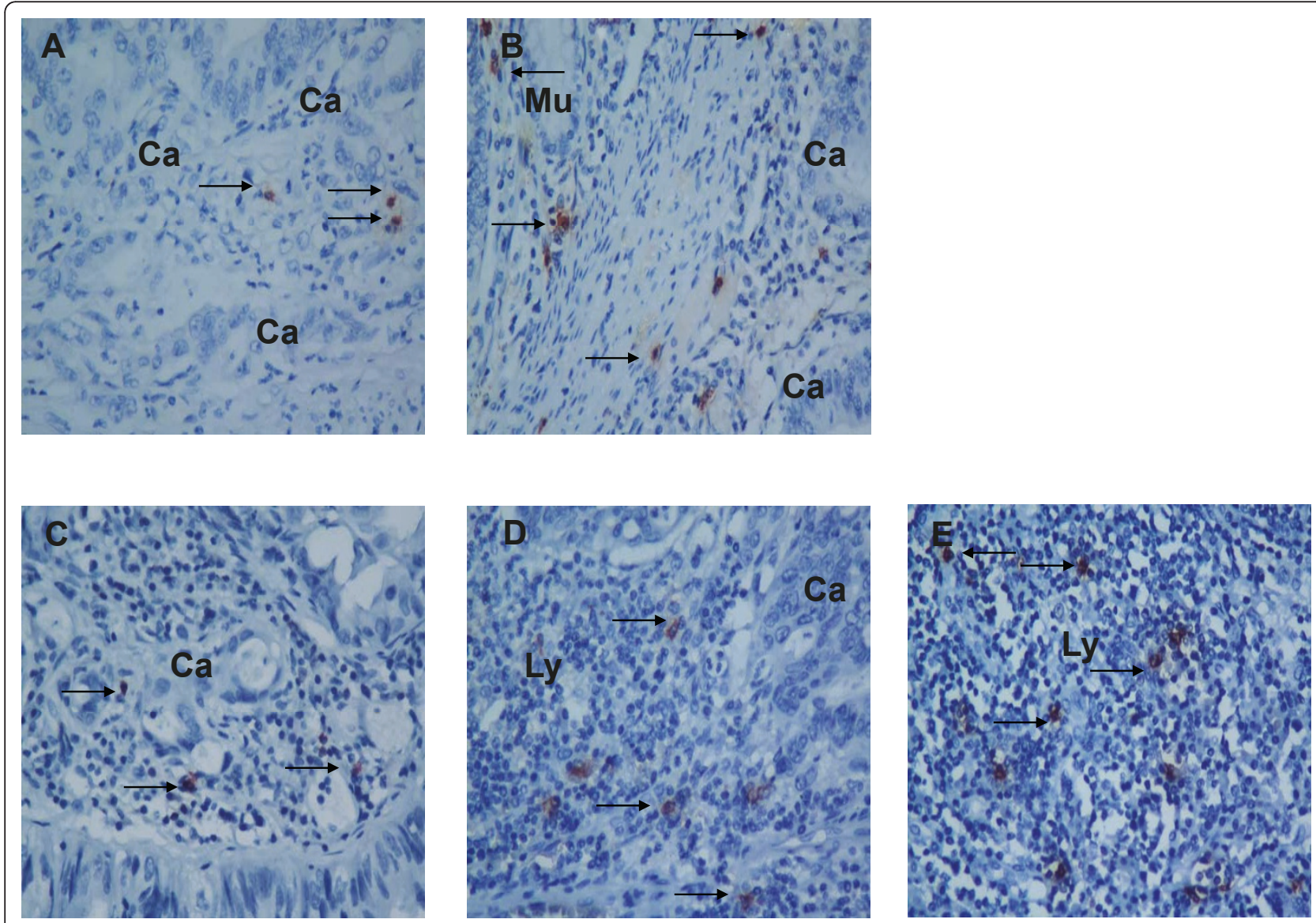

Figure 1 The distribution patterns of mast cells in primary colon cancer, lymph node metastasis and normal regional-draining lymph node. The tryptase-positive mast cells were stained using an immunohistochemical assay ( $\times 400)$. Higher frequencies of mast cells occurred in

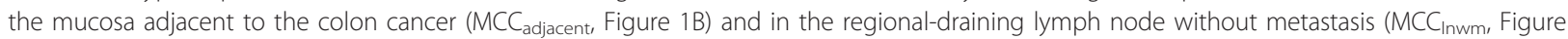
$1 \mathrm{E})$ than occurred in the lymph node metastasis $\left(\mathrm{MCC}_{\mathrm{sinm}}\right.$ and $\mathrm{MCC}_{\mathrm{alnm}}$, Figure $1 \mathrm{C}$ and Figure $\left.1 \mathrm{D}\right)$ and the stroma of the primary colon cancer $\left(\mathrm{MCC}_{\text {stromar }}\right.$ Figure 1A). Ca: cancer tissue; Ly: Iymph node; Mu: colon mucosa. 
Table 1 Mast cell counts in colon cancers

\begin{tabular}{lc}
\hline Location of mast cells & $\begin{array}{c}\text { Mast cell count } \\
\text { (median } \pm \text { interquartile range) }\end{array}$ \\
\hline MCC $_{\text {stroma* }}$ & $2.60 \pm 4.80$ \\
MCC $_{\text {adjacent }}$ & $10.60 \pm 8.90$ \\
MCC $_{\text {sInm }}$ & $4.00 \pm 5.90$ \\
MCC alnm & $5.20 \pm 4.90$ \\
MCC Inwm & $10.20 \pm 10.00$ \\
\hline
\end{tabular}

*: $\mathrm{MCC}_{\text {stromar }}$ the count of tryptase-positive mast cells in the cancer stroma of


in the normal mucosa adjacent to the colon cancer; $\mathrm{MCC}_{\mathrm{sInm}}$, the count of tryptase-positive mast cells in the stroma of matched lymph node metastasis; MCC $_{\text {alnm }}$, the count of tryptase-positive mast cells in the normal lymph tissue adjacent to the lymph node metastasis; MCC $_{\text {Inwm }}$ the count of tryptasepositive mast cells in the regional-draining lymph node without metastasis.

without metastasis were not correlated with OS (Table 3).

\section{Multivariate Cox proportional hazards analysis}

Multivariate Cox proportional hazards analysis was used to determine whether the mast cell counts in the primary tumor, lymph node metastasis and normal regional-draining lymph node could serve as independent predictors of OS. Variables included age, gender, location of primary tumor, pathologic classification, pathologic grade, growth pattern, tumor invasive depth and the distributions of mast cells $\left(\mathrm{MCC}_{\text {stroma }}, \mathrm{MCC}_{\text {adjacent }}, \mathrm{MCC}_{\text {slnm }}, \mathrm{MCC}_{\mathrm{alnm}}\right.$ and $\left.\mathrm{MCC}_{\text {lnwm }}\right)$. The results show that none of the variables was associated with OS (Table 4).

\section{Discussion}

Multiple studies have analyzed the role of mast cells in the progression of primary colon cancer. Initial studies indicated that mast cell properties are independent prognostic factors $[13,14]$. However, this conclusion was questioned by subsequent studies [15-18]. Most of these studies have significant weaknesses, such as the mixture of colon with rectal cancers, the mixture of TNM stages, and small sample sizes [15-19]. This study analyzed 93 stage IIIB colon cancer patients to avoid those shortcomings. The results show that, although the mast cell count in the normal mucosa adjacent to the primary colon cancer $\left(\mathrm{MCC}_{\mathrm{adjacent}}\right)$ was higher than that in the stroma of the primary colon tumor $\left(\mathrm{MCC}_{\text {stroma }}\right)$, neither $\mathrm{MCC}_{\text {adjacent }}$ nor $\mathrm{MCC}_{\text {stroma }}$ was correlated with the clinicopathologic parameters or 5-year survival rate. Therefore, in this patient population there was no direct evidence that infiltration of mast cells into primary cancer tissue impacted the progression of colon cancer.

Table 2 Correlations between various MCCs and clinicopathologic characteristics

\begin{tabular}{|c|c|c|c|c|c|c|c|c|c|c|c|}
\hline \multirow[t]{2}{*}{ Variable } & \multirow[t]{2}{*}{$n$} & \multirow{2}{*}{$\begin{array}{l}\mathrm{MCC}_{\text {stroma* }} \\
<2.6 \geq 2.6\end{array}$} & \multirow[t]{2}{*}{$P$} & \multirow{2}{*}{$\frac{\mathrm{MCC}_{\text {adjacent }}}{<10.6 \geq 10.6}$} & \multirow[t]{2}{*}{$P$} & \multirow{2}{*}{$\frac{\mathrm{MCC}_{\text {sInm }}}{<4.0 \geq 4.0}$} & \multirow[t]{2}{*}{$P$} & \multirow{2}{*}{$\frac{\mathrm{MCC}_{\mathrm{alnm}}}{<5.2 \geq 5.2}$} & \multirow[t]{2}{*}{$P$} & \multirow{2}{*}{$\begin{array}{l}\mathrm{MCC}_{\text {Inwm }} \\
<10.2 \geq 10.2\end{array}$} & \multirow[t]{2}{*}{$P$} \\
\hline & & & & & & & & & & & \\
\hline Age & & & 0.243 & & 0.911 & & 0.377 & & 0.121 & & 0.471 \\
\hline$<60$ & 43 & 1825 & & 2122 & & 2221 & & 2518 & & 2320 & \\
\hline$\geq 60$ & 50 & 2723 & & 2525 & & 2129 & & 2129 & & 2327 & \\
\hline Gender & & & 0.407 & & 0.574 & & 0.726 & 26 & 0.250 & & 0.045 \\
\hline Male & 58 & 3028 & & 3028 & & 2632 & & 2632 & & 2434 & \\
\hline Female & 35 & 1520 & & 1619 & & 1718 & & 2015 & & 2213 & \\
\hline Location of primary tumor & & & 0.431 & & 0.336 & & 0.094 & & 0.588 & & 0.472 \\
\hline Left & 54 & 2826 & & 2925 & & 2133 & & 2826 & & 2529 & \\
\hline Right & 39 & 1722 & & 1722 & & 2217 & & 1821 & & 2118 & \\
\hline Pathologic classification & & & 0.732 & & 0.652 & & 0.900 & & 0.038 & & 0.576 \\
\hline Papillary + tubular & 73 & 3637 & & 3736 & & 3439 & & 3241 & & 3538 & \\
\hline Mucoid + signet ring & 20 & 911 & & 911 & & 911 & & 146 & & 119 & \\
\hline Pathologic Grade & & & 0.799 & & 0.998 & & 0.991 & & & & 0.582 \\
\hline G1 & 2 & 11 & & 11 & & 11 & & 02 & 0.001 & 11 & \\
\hline $\mathrm{G} 2$ & 69 & 3237 & & 3435 & & 3237 & & 2841 & & 3237 & \\
\hline G3 & 22 & 1210 & & 1111 & & 1012 & & 184 & & 139 & \\
\hline Growth type & & & 1.000 & & 0.769 & & 0.239 & & & & 0.769 \\
\hline Pushing & 31 & 1516 & & 1615 & & 1714 & & 1813 & & 1615 & \\
\hline Infiltrating & 62 & 3032 & & 3032 & & 2636 & & 2834 & 0.241 & 3032 & \\
\hline Invasive depth & & & 0.683 & & 0.293 & & 0.826 & & & & 0.615 \\
\hline $\mathrm{T} 3$ & 77 & 3839 & & 4037 & & 3641 & & 3938 & & 3938 & \\
\hline $\mathrm{T} 4$ & 16 & 79 & & 610 & & 79 & & 79 & 0.615 & 79 & \\
\hline
\end{tabular}

*: MCC $_{\text {stromar }}$ the count of tryptase-positive mast cells in the cancer stroma of the primary colon tumor; MCC $_{\text {adjacent, }}$ the count of tryptase-positive mast cells in the normal mucosa adjacent to the colon cancer; $M_{C C_{s} n m}$, the count of tryptase-positive mast cells in the stroma of matched lymph node metastasis; MCC $_{\text {alnm }}$ the count of tryptase-positive mast cells in the normal lymph tissue adjacent to the lymph node metastasis; MCC $_{\text {Inwm }}$, the count of tryptase-positive mast cells in the regional-draining lymph node without metastasis. 
Table 3 Univariate analysis of factors associated with OS

\begin{tabular}{|c|c|c|}
\hline \multirow[t]{2}{*}{ Variable } & \multicolumn{2}{|l|}{ OS $(n=93)$} \\
\hline & $\mathrm{HR},(95 \% \mathrm{Cl})$ & $P$ \\
\hline Age (<60 y vs. $\geq 60$ y) & $0.635(0.291-1.386)$ & 0.249 \\
\hline Gender (female vs. male) & $1.158(0.537-2.495)$ & 0.707 \\
\hline Location of primary tumor (right vs. left) & $1.915(0.896-4.093)$ & 0.087 \\
\hline $\begin{array}{l}\text { Pathologic classification (mucoid }+ \text { signet } \\
\text { ring vs. papillary }+ \text { tubular) }\end{array}$ & $2.325(1.043-5.183)$ & 0.033 \\
\hline Pathologic grade (G3 vs. G2 + G1) & $1.749(0.785-3.894)$ & 0.165 \\
\hline Growth type (infiltrating vs. pushing) & $0.856(0.392-1.870)$ & 0.696 \\
\hline Invasive depth (T4 vs. T3) & $0.853(0.295-2.466)$ & 0.768 \\
\hline $\mathrm{MCC}_{\text {stroma }}{ }^{*}(\geq 2.6 \mathrm{MC} / \mathrm{HP}$ vs. $<2.6 \mathrm{MC} / \mathrm{HP})$ & $1.224(0.573-2.615)$ & 0.600 \\
\hline $\begin{array}{l}\mathrm{MCC}_{\text {adjacent }}(\geq 10.6 \mathrm{MC} / \mathrm{HP} \text { vs. }<10.6 \\
\mathrm{MC} / \mathrm{HP})\end{array}$ & $0.943(0.443-2.006)$ & 0.878 \\
\hline $\mathrm{MCC}_{\text {sInm }}(\geq 4.0 \mathrm{MC} / \mathrm{HP}$ vs. $<4.0 \mathrm{MC} / \mathrm{HP})$ & $1.588(0.727-3.469)$ & 0.241 \\
\hline $\mathrm{MCC}_{\mathrm{alnm}}(\geq 5.2 \mathrm{MC} / \mathrm{HP}$ vs. $<5.2 \mathrm{MC} / \mathrm{HP})$ & $1.045(0.491-2.223)$ & 0.909 \\
\hline $\mathrm{MCC}_{\text {Inwm }}(\geq 10.2 \mathrm{MC} / \mathrm{HP}$ vs. $<10.2 \mathrm{MC} / \mathrm{HP})$ & $0.779(0.365-1.665)$ & 0.518 \\
\hline
\end{tabular}

*: $\mathrm{MCC}_{\text {stromar }}$ the count of tryptase-positive mast cells in the cancer stroma of the primary colon tumor; $\mathrm{MCC}_{\text {adjacent, }}$ the count of tryptase-positive mast cells in the normal mucosa adjacent to the colon cancer; $\mathrm{MCC}_{\mathrm{sinm}}$, the count of tryptase-positive mast cells in the stroma of matched lymph node metastasis; $M \mathrm{MC}_{\text {alnm, }}$, the count of tryptase-positive mast cells in the normal lymph tissue adjacent to the lymph node metastasis; $M \mathrm{MC}_{\text {Inwm, }}$ the count of tryptasepositive mast cells in the regional-draining lymph node without metastasis.

These results also refute the randomized distribution model of mast cells in cancer tissues suggested by Ribatti [20]. The reason that this kind of non-randomized distribution of mast cells would not impact the progression of colon cancer is unclear, it is possible that the role of mast cells was outweighed by that of angiogenesis, which is induced by multiple factors, including mast cells [21-23].

Table 4 Multivariate Cox analysis of factors associated with OS

\begin{tabular}{|c|c|c|}
\hline \multirow[t]{2}{*}{ Variable } & \multicolumn{2}{|l|}{ OS $(n=93)$} \\
\hline & $\mathrm{HR},(95 \% \mathrm{Cl})$ & $P$ \\
\hline Age $(<60$ y vs. $\geq 60$ y) & $0.497(0.219-1.127)$ & 0.094 \\
\hline Gender (female vs. male) & $1.302(0.571-2.969)$ & 0.531 \\
\hline Location of primary tumor (right vs. left) & $2.220(0.922-5.345)$ & 0.075 \\
\hline $\begin{array}{l}\text { Pathologic classification (mucoid + signet } \\
\text { ring vs. papillary + tubular) }\end{array}$ & $2.514(0.662-9.537)$ & 0.175 \\
\hline Pathologic grade (G3 vs. G2 + G1) & $1.108(0.300-4.094)$ & 0.877 \\
\hline Growth type (infiltrating vs. pushing) & $1.195(0.489-2.917)$ & 0.696 \\
\hline Invasive depth (T4 vs. T3) & $1.456(0.464-4.569)$ & 0.520 \\
\hline $\mathrm{MCC}_{\text {stroma }}{ }^{*}(\geq 2.6 \mathrm{MC} / \mathrm{HP}$ vs. $<2.6 \mathrm{MC} / \mathrm{HP})$ & $1.180(0.524-2.659)$ & 0.690 \\
\hline $\mathrm{MCC}_{\text {adjacent }}(\geq 10.6 \mathrm{MC} / \mathrm{HP}$ vs. $<10.6 \mathrm{MC} / \mathrm{HP})$ & $0.812(0.372-1.774)$ & 0.602 \\
\hline $\mathrm{MCC}_{\mathrm{sInm}}(\geq 4.0 \mathrm{MC} / \mathrm{HP}$ vs. $<4.0 \mathrm{MC} / \mathrm{HP})$ & $1.890(0.748-4.773)$ & 0.178 \\
\hline $\mathrm{MCC}_{\mathrm{alnm}}(\geq 5.2 \mathrm{MC} / \mathrm{HP}$ vs. $<5.2 \mathrm{MC} / \mathrm{HP})$ & $0.916(0.354-2.367)$ & 0.856 \\
\hline $\mathrm{MCC}_{\text {Inwm }}(\geq 10.2 \mathrm{MC} / \mathrm{HP}$ vs. $<10.2 \mathrm{MC} / \mathrm{HP})$ & $0.729(0.329-1.614)$ & 0.436 \\
\hline
\end{tabular}

*: $\mathrm{MCC}_{\text {stromar }}$ the count of tryptase-positive mast cells in the cancer stroma of the primary colon tumor; $\mathrm{MCC}_{\text {adjacent, }}$ the count of tryptase-positive mast cells in the normal mucosa adjacent to the colon cancer; $\mathrm{MCC}_{\mathrm{sinm}}$, the count of tryptase-positive mast cells in the stroma of matched lymph node metastasis; $\mathrm{MCC}_{\text {alnm, }}$ the count of tryptase-positive mast cells in the normal lymph tissue adjacent to the lymph node metastasis; MCC $_{\text {Inwm }}$, the count of tryptasepositive mast cells in the regional-draining lymph node without metastasis.
Since IIIB is a locally advanced stage and the potential effects of mast cells may be stronger in earlier stages of colon cancer development such as stage I, stage II and their function in metastatic disease may show quite different results. We analyzed this in the early research work and found the consistent result. Paraffin-embedded specimens, including tumor tissues and adjacent normal mucosa tissues obtained from 39 patients with pathologic evaluation-confirmed colon adenomas and 155 patients with colon cancers (the samples from stage I to IV were $38,38,38,41$ ), who underwent radical surgery or biopsy during the same period were analyzed using the same method. Results showed that the majority of mast cells were located in the normal mucosa adjacent to the colon cancer too, followed by the invasive margin and then cancer stroma. The mast cell count in the normal mucosa adjacent to the colon cancer was associated with the TNM classification characteristics and hepatic metastases, although it was not a prognostic factor. Otherwise, the mast cell count in the invasive margin was associated with neither the clinicopathlogic parameters nor overall survival, since the mast cell in the cancer stroma was rare, we didn't analyze it.

In addition to infiltrating primary tumors, mast cells also infiltrate metastases. The role of mast cells in metastasis is still not known. Therefore, this study examined the infiltration of mast cells in lymph node metastasis. In contrast to the infiltration of mast cells in the primary tumor, a similar distribution of mast cells occurred both in the stroma of lymph node metastasis $\left(\mathrm{MCC}_{\text {sInm }}\right)$ and in the lymph tissue adjacent to the metastasis $\left(\mathrm{MCC}_{\mathrm{alnm}}\right)$. Although $\mathrm{MCC}_{\mathrm{alnm}}$ was higher in papillary and tubular adenomas than in mucoid and signet ring adenomas, and although higher $\mathrm{MCC}_{\mathrm{alnm}}$ occurred in lower-grade colon cancers, neither $\mathrm{MCC}_{\text {slnm }}$ nor $\mathrm{MCC}_{\mathrm{alnm}}$ was correlated with 5-year survival, which suggests that mast cells are not involved in lymph node metastasis.

Because mast cells might impact tumor progression by regulating the immune microenvironment of regionaldraining lymph nodes, this study also examined the mast cell count in the regional-draining lymph node without metastasis [24-27]. The results show that the mast cell count in this lymph node $\left(\mathrm{MCC}_{\text {lnwm }}\right)$ was $(10.20 \pm 10.00) / \mathrm{HP}$, significantly higher than $\mathrm{MCC}_{\text {slnm }}$ and $\mathrm{MCC}_{\mathrm{alnm}}$. However, $\mathrm{MCC}_{\mathrm{lnwm}}$ was not correlated the 5-year survival, which again fails to support the hypothesis that mast cells contribute to the progression of colon cancer by an indirect mechanism.

Furthermore, the 5-year survival rate was $70.9 \%$ in our study, a little higher than an analysis of Surveillance, Epidemiology, and End Results (SEER) data (64.1\%) [28]. Most of the cases were N1 status with 12 or more lymph nodes examined may help partially explain such a result. However, our study existed some limitations. For 
example, only 93 continual colon cancer patients were collected, sample was not big enough and there may be some selection bias thus further research is needed.

\section{Conclusion}

By examining the distribution of mast cells in the primary tumor, in lymph node metastasis and in the normal regional-draining lymph node in 93 stage IIIB colon cancer patients, we found that, although the counts of mast cells varied with location, none of the mast cell counts was correlated with the 5-year survival rate. These data argue against the hypothesis that mast cells are involved in the progression of stage IIIB colon cancer.

\section{List of abbreviations used}

MCC adjacent : the count of tryptase-positive mast cells in the normal mucosa adjacent to the colon cancer; MCC $_{\text {alnm }}$ : the count of tryptase-positive mast cells in the normal lymph tissue adjacent to the lymph node metastasis; $\mathrm{MCC}_{\text {Inwm }}$ : the count of tryptase-positive mast cells in the regional-draining lymph node without metastasis; MCC $_{\text {sInm }}$ : the count of tryptase-positive mast cells in the stroma of matched lymph node metastasis; $M C C_{\text {stroma }}$ : the count of tryptase-positive mast cells in the cancer stroma of the primary colon tumor. OS: Overall survival;

\section{Acknowledgements}

This study was supported by research grants from the National (30972882) and the Nature Science Foundation of Guangdong Province, China (9151008901000149)

\section{Author details \\ 'State Key Laboratory of Oncology in South China, Sun Yat-sen University Cancer Center, Guangzhou 510060, China. ${ }^{2}$ Biotherapy Center, Sun Yat-sen University Cancer Center, Guangzhou 510060, China. ${ }^{3}$ Department of Colorectal Oncology, Sun Yat-sen University Cancer Center, Guangzhou 510060, China. ${ }^{4}$ Department of Pathology, Sun Yat-sen University Cancer Center, Guangzhou 510060, China. ${ }^{5}$ Department of Medical Oncology, The First People Hospital of Yueyang, Yueyang 414000, China.}

\section{Authors' contributions}

WXJ and PZZ performed the case collection. XQ and HJH performed the immunohistochemical staining. ZJ and ZQ analyzed the results. ZXS conceived the study, participated in the study design, and coordinated the writing and helped draft the manuscript. All authors read and approved the final manuscript.

\section{Competing interests}

The authors declare that they have no competing interests.

Received: 2 December 2010 Accepted: 9 June 2011

Published: 9 June 2011

\section{References}

1. Ferrone C, Dranoff G: Dual roles for immunity in gastrointestinal cancers. $J$ Clin Oncol 2010, 28(26):4045-4051

2. Pagès F, Galon J, Dieu-Nosjean MC, Tartour E, Sautès-Fridman C, Fridman WH: Immune infiltration in human tumors: a prognostic factor that should not be ignored. Oncogene 2010, 29(8):1093-1102.

3. Zhou Q, Peng RQ, Wu XJ, Xia Q, Hou JH, Ding Y, Zhou QM, Zhang X, Pang ZZ, Wan DS, Zeng YX, Zhang XS: The density of macrophages in the invasive front is inversely correlated to liver metastasis in colon cancer. $J$ Transl Med 2010, 8:13.

4. Peng RQ, Wu XJ, Ding Y, Li CY, Yu XJ, Zhang X, Pan ZZ, Wan DS, Zheng LM, Zeng YX, Zhang XS: Co-expression of nuclear and cytoplasmic HMGB1 is inversely associated with infiltration of CD45RO+ T cells and prognosis in patients with stage IIIB colon cancer. BMC Cancer 2010, 10:496.

5. Kmieciak M, Gowda M, Graham L, Godder K, Bear HD, Marincola FM, Manjili MH: Human T cells express CD25 and Foxp3 upon activation and exhibit effector/memory phenotypes without any regulatory/suppressor function. J Trans/ Med 2009, 7:89.

6. Gao YF, Peng RQ, Li J, Ding Y, Zhang X, Wu XJ, Pan ZZ, Wan DS, Zeng YX, Zhang XS: The paradoxical patterns of expression of indoleamine 2,3dioxygenase in colon cancer. J Transl Med 2009, 7:71.

7. Maltby S, Khazaie K, McNagny KM: Mast cells in tumor growth: angiogenesis, tissue remodelling and immune-modulation. Biochim Biophys Acta 2009, 1796(1):19-26.

8. Ribatti $\mathrm{D}$, Crivellato $\mathrm{E}$ : The controversial role of mast cells in tumor growth. Int Rev Cell Mol Biol 2009, 275:89-131.

9. Galinsky DS, Nechushtan $\mathrm{H}$ : Mast cells and cancer-no longer just basic science. Crit Rev Oncol Hematol 2008, 68(2):115-130.

10. Groot Kormelink T, Abudukelimu A, Redegeld FA: Mast cells as target in cancer therapy. Curr Pharm Des 2009, 15(16):1868-1878.

11. Gounaris E, Erdman SE, Restaino C, Gurish MF, Friend DS, Gounari F, Lee DM, Zhang G, Glickman JN, Shin K, Rao VP, Poutahidis T, Weissleder R, McNagny KM, Khazaie K: Mast cells are an essential hematopoietic component for polyp development. Proc Natl Acad Sci USA 2007, 104(50):19977-19982.

12. Gounaris E, Blatner NR, Dennis K, Magnusson F, Gurish MF, Strom TB, Beckhove P, Gounari F, Khazaie K: T-regulatory cells shift from a protective anti-inflammatory to a cancer-promoting proinflammatory phenotype in polyposis. Cancer Res 2009, 69(13):5490-5497.

13. Fisher ER, Paik SM, Rockette H, Jones J, Caplan R, Fisher B: Prognostic significance of eosinophils and mast cells in rectal cancer: findings from the National Surgical Adjacent Breast and Bowel Project (protocol R-01). Hum Pathol 1989, 20(2):159-163.

14. Nielsen HJ, Hansen U, Christensen IJ, Reimert CM, Brünner N, Moesgaard F: Independent prognostic value of eosinophil and mast cell infiltration in colorectal cancer tissue. J Pathol 1999, 189(4):487-495.

15. Gulubova M, Vlaykova T: Prognostic significance of mast cell number and microvascular density for the survival of patients with primary colorectal cancer. J Gastroenterol Hepatol 2009, 24(7):1265-1275.

16. Yodavudh S, Tangjitgamol S, Puangsa-art S: Prognostic significance of microvessel density and mast cell density for the survival of Thai patients with primary colorectal cancer. J Med Assoc Thai 2008, 91(5):723-732.

17. Acikalin MF, Oner U, Topçu I, Yaşar B, Kiper H, Colak E: Tumour angiogenesis and mast cell density in the prognostic assessment of colorectal carcinomas. Dig Liver Dis 2005, 37(3):162-169.

18. Tan SY, Fan Y, Luo HS, Shen ZX, Guo Y, Zhao LJ: Prognostic significance of cell infiltrations of immunosurveillance in colorectal cancer. World J Gastroenterol 2005, 11(8):1210-1214.

19. Kalady MF, Sanchez JA, Manilich E, Hammel J, Casey G, Church JM: Divergent Oncogenic Changes Influence Survival Differences between Colon and Rectal Adenocarcinomas. Diseases of the Colon \& Rectum 2009, 52(6):1039-1045

20. Guidolin D, Nico B, Crivellato E, Marzullo A, Vacca A, Ribatti D: Tumoral mast cells exhibit a common spatial distribution. Cancer Lett 2009, 273(1):80-85.

21. Nechushtan $\mathrm{H}$ : The complexity of the complicity of mast cells in cancer. Int J Biochem Cell Biol 2010, 42(5):551-554.

22. Crivellato E, Nico B, Ribatti D: Mast cell contribution to tumor angiogenesis: a clinical approach. Eur Cytokine Netw 2009, 20(4):197-206.

23. Crivellato E, Nico B, Ribatti D: Mast cells and tumour angiogenesis: new insight from experimental carcinogenesis. Cancer Lett 2008, 269(1):1-6.

24. Galli SJ, Grimbaldeston M, Tsai M: Immunomodulatory mast cells: negative, as well as positive, regulators of immunity. Nat Rev Immunol 2008, 8(6):478-486.

25. Kalesnikoff J, Galli SJ: New developments in mast cell biology. Nat Immunol 2008, 9(11):478-1223.

26. Cochran AJ, Huang RR, Lee J, Itakura E, Leong SP, Essner R: Tumourinduced immune modulation of sentinel lymph nodes. Nat Rev Immunol 2006, 6(9):659-670.

27. Preynat-Seauve $\mathrm{O}$, Contassot $\mathrm{E}$, Schuler $\mathrm{P}$, Piguet $\mathrm{V}$, French LE, Huard $\mathrm{B}$ : Extralymphatic tumors prepare draining lymph nodes to invasion via a T-cell cross-tolerance process. Cancer Res 2007, 67(10):5009-5016.

28. O'Connell JB, Maggard MA, Ko CY: Colon cancer survival rates with the new American Joint Committee on Cancer sixth edition staging. J Natl Cancer Inst 2004, 96(19):1420-1425.

doi:10.1186/1479-5876-9-88

Cite this article as: Xia et al: No relationship between the distribution of mast cells and the survival of stage IIIB colon cancer patients. Journal of Translational Medicine 2011 9:88. 